\title{
MUSEUM TROWULAN DAN \\ HISTORIOGRAFI MAJAPAHIT \\ PENGUAT IDENTITAS BANGSA
}

\author{
Abraham Nurcahyo ${ }^{1}$ )
}

\begin{abstract}
Abstrak
Museum Indonesia selama ini kaya koleksi, tetapi miskin informasi. Pengunjung hanya menikmati benda kuno, bukan gagasan, pengetahuan atau pesan yang bermanfaat untuk saat ini. Founding father paham benar, pentingnya mewarisi kejayaan Majapahit. Mewarisi tinggalan sejarah merupakan bagian dari mewarisi sejarah itu sendiri. Informasi terpadu berupa data tertulis, digital, gambar maupun peninggalan pada masa Majapahit dapat diakses secara lengkap pada Pusat Informasi Majapahi. Dalam struktur pemerintahan Majapahit, raja memegang otoritas tertinggi dan dianggap sebagai penjelmaan Dewa di dunia. Pola pemerintahannya menganut konsep kosmogoni, penggabungan pengaruh dua kekuatan ajaran Hinduisme dan Budhisme. Menurunnya kecintaan bangsa ini pada tanah air bermula dari hilangnya kesadaran sejarah, geografis, dan budaya kita. Penguatan identitas bangsa akan lebih efektif jika semua lapisan masyarakat terlibat didalamnya serta diperlukan kemauan politik oleh pengambil kebijakan.
\end{abstract}

\section{Kata kunci: Museum, Historiografi, Identitas Bangsa}

1) Abraham Nurcahyo adalah Dosen Pendidikan Sejarah IKIP PGRI Madiun; Jl Setiabudi 85 Madiun; email: abrahamnurcahyo@yahoo.co.id. 


\section{Pendahuluan}

Budaya Majapahit menarik diungkap dan hasilnya tentunya akan membanggakan bangsa Indonesia. Guna merekonstruksi kehidupan masyarakat pada masa lampau, budaya Majapahit penting dikaji. Para tokoh pergerakan Indonesia pada awal abad ke-20, telah terinspirasi Majapahit sebagai kerajaan besar negeri ini.

Seringkali Majapahit dijadikan referensi oleh para pemangku kebijakan. (Ricklefs, 2008:56). Dalam propaganda yang dijalankan tahun 1920-an, Partai Komunis Indonesia menyampaikan visinya tentang masyarakat tanpa kelas sebagai penjelmaan kembali dari Majapahit yang diromantiskan (Ricklefs, 2008:363). Bung Karno mengangkat isue Majapahit guna kepentingan persatuan bangsa, sedangkan Orde Baru memaknainya demi perluasan dan konsolidasi kekuasaan negara (Th.G. Pigeuad, 1962:19).

Majapahit merupakan simbol kejayaan bangsa Indonesia. Para founding father paham, pentingnya mewarisi kejayaan Majapahit. Tidak mengherankan bila banyak nilai yang digali oleh para pendiri bangsa dalam meletakkan dasar negara ini. Semboyan Bhinneka Tunggal Ika diambil dari karya sastra era Majapahit, dari kitab Sutasoma karya Mpu Tantular. Demikian pula, bendera Merah Putih diilhami panjipanji Gula Kelapa dari Majapahit, yang memiliki warna merah seperti gula (jawa) dan putih seperti kelapa.
Sumpah Palapa Gajah Mada menjadi simbol persatuan NKRI, Negara Kesatuan Republik Indonesia (M. Yamin, 1962). Pentingnya melestarikan warisan benda bersejarah, bukan hanya terletak pada bentuk, model, dan dari apa benda tersebut terbuat. Namun, mewarisi tinggalan sejarah merupakan bagian dari mewarisi sejarah itu sendiri. Sebagian tinggalan budaya Majapahit kini tersimpan di museum Trowulan. Benda-benda sejarah merupakan citra peradaban masyarakat pada masanya. Melalui tinggalan budaya, kita bisa menarik pelajaran mengenai aktivitas yang dilakukannya.

Pemberian informasi ini akan berhasil bila sejak awal ditanamkan kesadaran kepada semua pihak bahwa museum bukan gudang penyimpanan benda-benda kuno. Melainkan, sebagai pusat informasi perjalanan sejarah bangsa-nya, sehingga tinggalan budaya yang mencerminkan peradaban bangsa terawat dengan baik. Akan tetapi, kesadaran ini belum tumbuh di kalangan masyarakat dan birokrasi pemerintahan. Museum sebagai pembentuk dan penghubung peradaban bangsa masih diabaikan. Studi ini akan menjawab pentingnya museum Trowulan dan historiografi Majapahit sebagai penguat identitas bangsa.

\section{Museum Trowulan dan Pengembangannya}

Pada abad 17, museum me- 
nyimpan koleksi benda-benda asing, langka dan eksotik yang disumbangkan Elias Ashmole pada Universitas Oxford. Dari koleksi milik pribadi, kemudian berkembang menjadi institusi pendidikan publik (Ambrose dan Paine, 1998). Berdirinya, museum Trowulan, tidak lepas dari jasa Bupati Mojokerto, R.A.A. Kromodjojo Adinegoro. Pada tanggal 24 April 1924, Henry Maclaine Pont mendidirikan Oudheeidkundige Vereebeging Majapahit (OVM) yaitu suatu perkumpulan yang bertujuan meneliti peninggalanpeninggalan Majapahit. Seiring dengan me-ningkatnya koleksi yang dimiliki maka pada tahun 1926 para pe-mrakarsa OVM mendirikan museum. Pada masa pendudukan Jepang (1942), Henry Maclaine Pont ditawan, sehingga pengelolaan museum diambil alih oleh pemerintah.

Setelah merdeka, museum Trowulan dikelola oleh Lembaga Suaka Peninggalan Sejarah dan Purbakala (SPSP) dibawah kendali Balai Pelestarian Peninggalan Purbakala (BP3) Jawa Timur. Selain mengelola museum, lembaga tersebut melakukan perlindungan benda purbakala di seluruh wilayah Jawa Timur dengan sebutan Balai Penyelamatan Arca. Meski demikian, masyarakat mengenalnya dengan nama museum Trowulan. Pada tahun 1999, jumlah koleksinya bertambah banyak, hasil pemindahan dan penggabungan koleksi Gedung Arca Mojokerto dengan museum Trowulan. Tanggal 3 November 2008, Balai Penyelamatan Arca atau museum Trowulan diubah menjadi
Pusat Informasi Majapahit (PIM) yang diresmikan langsung oleh Menteri Pendidikan dan Kebudayaan Jero Wacik. Penamaan tersebut didasarkan atas peningkatan kebutuhan masyarakat menyangkut informasi tentang Majapahit baik oleh peneliti maupun masyarakat umum. Sebuah informasi terpadu berupa data tertulis, digital, gambar maupun peninggalan pada jaman Majapahit nantinya dapat diakses secara lengkap di Pusat Informasi Majapahit. Walaupun nama dan bentuk kegiatannya telah mengalami perubahan dan perkembangan, tetapi fungsi dan tujuan dasarnya tidak berubah, tetap sebagai museum dan Balai Penyelamatan Benda Cagar Budaya di Jawa Timur.

Berdasarkan bahannya, koleksi PIM dapat diklasifikasikan sebagai berikut: a) koleksi tanah liat (terakota) mencakup terakota manusia (figur), alat-alat produksi, alat-alat rumah tangga, dan arsitektur; b) koleksi keramik antara lain guci, teko, piring, mangkok, sendok, dan vas bunga berasal dari Cina, Thailand, dan Vietnam; c) koleksi logam antara lain uang kuno, alatalat seperti bokor, pedupaan, lampu, guci, cermin, genta, dan alat usik; d) koleksi batu terdiri dari miniatur dan komponen candi, koleksi arca, koleksi relief, dan koleksi prasasti.

Pemanfaatan benda cagar budaya koleksi PIM sejalan dengan pengertian museum menurut International Council of Museums (ICOM) bahwa museum merupakan badan tetap, nirlaba, dan harus terbuka untuk umum. Sebagai sarana sosialbudaya yang terbuka, melalui benda- 
benda koleksinya, museum dapat memberikan informasi berharga kepada masyarakat luas (informative function). Hal ini merupakan representasi museum sebagai lembaga pelayanan publik. Fungsi edukatif museum dapat dipaparkan sebagai berikut. Melalui benda-benda koleksi yang dipamerkan, museum menyajikan informasi kepada masyarakat. Dengan mengunjungi museum, seseorang dapat belajar maupun menambah pengetahuannya misalnya ia dapat mengetahui perkembangan peradaban manusia lewat benda-benda koleksi museum. Pendidikan merupakan proses alih pengetahuan (transfer of knowledge) baik melalui pendidikan formal maupun pendidikan luar sekolah (informal). Dalam aspek pendidikan, museum menyimpan berbagai informasi bagi dunia ilmu pengetahuan berkait dengan disiplin: teknologi, geologi, geografi, ilmu lingkungan hidup, sosial-ekonomi, serta antropologi budaya. Bagi peserta didik (para murid), peninggalan arkeologis selain mampu memperkaya pengetahuan mereka serta menjadi media pendidikan moral dalam rangka pengembangan kepribadian (character building).

Pengelola museum selanjutnya memberi pemahaman bahwa museum bukan sekadar menyajikan benda tanpa makna. Museum harus memperhatikan gagasan serta pesan dan informasi yang cukup. Museum Indonesia selama ini kaya koleksi, tetapi miskin informasi. Pengunjung hanya menikmati benda kuno, bukan gagasan, pengetahuan atau pesan yang bermanfaat untuk saat ini. Jika museum akan diarahkan sebagai pembentuk jati diri bangsa, hendaknya museum menyajikan informasi yang lengkap terkait dengan citra budaya, sejarah budaya yang panjang dan pencapaian budaya bangsa.

PIM selain melayani kebutuhan para arkeolog dan sejawatnya, juga memperhatikan kebutuhan masyarakat luas terhadap pengetahuan, khususnya mengenai masa lalu manusia (Crowther, 1991). Dalam konteks itu, PIM tidak dapat bersikap pasif menunggu datangnya para pengunjung. Justru aktif mengenalkan keberadaan museum tersebut pada masyarakat. Agenda tahunan dibuat menyangkut event budaya serta strategi promosinya agar masyarakat berkunjung ke museum. Setiap pengelola museum harus mengetahui apa produk yang menjadi andalan museumnya. Pada dasar produk museum menyangkut layanan (services) khususnya informasi bagi para pengunjung. Produk layanan utama museum arkeologi Trowulan adalah informasi komprehensif mengenai kehidupan masyarakat kota pada masa Majapahit. Informasi yang disediakan mencakup bidang teknologi, kesenian, religi, mata pencaharian, ekonomi. Informasi tersebut disediakan dalam berbagai kemasan baik lisan, cetakan, maupun audio visual, maupun website.

Dari waktu ke waktu, relevansi museum sebagai sumber data dan informasi semakin meningkat. Bahkan akhir-akhir ini bermunculan museum khusus yang hanya berkaitan dengan disiplin ilmu, lembaga atau bidang tertentu (Tanudirjo, 
1998). Selain itu, museum Trowulan dapat memiliki fungsi rekreatif dalam arti sebagai tempat yang menarik bagi pengunjung yang ingin sekedar rekreasi. Dalam hal ini yang menjadi prioritas adalah membuat pengunjung senang, betah (tinggal lebih lama), dan pulang dengan membawa kesan baik. Kesan baik merupakan salah satu ujung tombak cara meningkatkan jumlah kunjungan.

Seorang pengunjung yang baik tentunya berupaya berkomunikasi dengan benda-benda koleksi museum. Mengingat tidak semua pengunjung museum memiliki kemampuan yang sama untuk menangkap (memahami) informasi dari benda koleksi, maka idealnya museum melengkapi koleksinya dengan informasi ringkas dan mudah dipahami oleh pengunjung. Setidaknya ada delapan katagori pengunjung, yaitu profesional arkeologi dan antropologi, arkeologi amatir, kolektor, akademisi, turis, masyarakat umum, pendidik, dan pelajar dan mahasiswa (Iseminger, 1997). Guna mengatasi hal ini disediakan tenaga atau petugas pemandu bagi para pengunjung museum. Dengan cara demikian, museum dapat memainkan fungsi yang diembannya sebagai sumber informasi kepada khalayak.

Masyarakat sering memiliki konsep yang tidak tepat mengenai masa lalu bangsa kita khususnya kerajaan Majapahit disebabkan oleh pengaruh media cetak maupun elektronika dan pewarisan sejarah secara lisan. Bahkan para guru sekalipun sering salah dalam memahami peristiwa sejarah hanya berdasarkan buku yang dibacanya. Museum arkeologi harus dapat meluruskan kesalahan tersebut dengan menyajikan informasi selengkap mungkin melalui pameran benda-benda koleksinya baik secara kronologis maupun tematis. Contoh pameran tematis sederhana seperti gambaran kehidupan ekonomi masyarakat Majapahit yang telah mengenal timbangan dan mata uang sebagai alat pembayaran. Pameran ini mengenalkan artefak berupa bandul timbangan, mata uang, celengan (tabungan dari gerabah), relief perdagangan, relief layanan jasa, parasasti yang memuat pajak, dan berbagai alat untuk mencari nafkah. Selain melakukan layanan pendidikan, pengelola museum dapat melakukannya di luar. Salah satu contoh yang dapat dikemukakan adalah program museum goes to school atau museum goes to mall. Intinya, museum bertindak lebih aktif mendekati calon pelanggannya. Dengan melakukan kegiatan seperti ini, museum dapat meraih manfaatnya. Publik akan lebih mengenal keberadaan museum, sedangkan pihak museum akan dapat mengetahui kemauan publik. Manfaat lainnya, dapat memupuk rasa bangga masyarakat terhadap kekayaan budaya bangsa.

Proses pembelajaran dalam arti luas tidak terbatas hanya di ruang kelas (classroom) dan lingkungan sekolah. Lingkungan sekitar dimana proses pembelajaran tersebut diselenggarakan juga tercakup di dalamnya. Cakupan arti yang demikian bukan hanya berlaku untuk Pendidikan Luar Sekolah (PLS), 
tetapi juga diterapkan pada pendidikan formal baik dalam rangka pengajaran Ilmu Pengetahuan Sosial (IPS), Ilmu Pengetahuan Alam (IPA), maupun Ilmu Pengetahuan Budaya (IPB). Urgensi lingkungan sekitar sebagai sumber belajar dirasakan semakin besar ketika dikaitkan dengan kebutuhan akan muatan lokal dalam kurikulum pendidikan di sekolah. Muatan lokal meliputi berbagai aspek kehidupan yang khas bagi wilayah tertentu, baik yang berkenaan dengan pengetahuan alam maupun budaya. Keduanya merupakan kondisi-kondisi khas di setiap daerah (Sedyawati, 1996).

Berbeda dengan open air museum dan on-site museum, museum didirikan di dalam kawasan situs arkeologi, sehingga keterkaitan koleksi dengan situsnya mudah di pahami. Cakupan bidang kerja museum situs di arahkan untuk mengumpulkan, meneliti, merawat, mengamankan, menyebarluaskan informasi, dan menyajikan bendabenda (artefak) dari situs arkeologi. Dalam kaitannya dengan penafsiran koleksi dan melakukan edukasi serta layanan kepada masyarakat, maka peran museum situs menjadi signifikan. Oleh karena dapat memberi gambaran atau mengarah-kan pengunjung sebelum mereka mengunjungi atau memahami nilai penting kearifan nenek moyang di masa lampau secara langsung di lapangan. Berkaitan dengan pentingnya fungsi yang dijalankan museum situs, maka museum tersebut harus dikelola secara mandiri, sehingga dapat mengembangkan program- programnya sesuai dengan kaidah per- museuman. Di Indonesia banyak terdapat situs dan kawasan arkeolog yang sangat potensial dan layak untuk didirikan museum situs. Museum situs arkeologi memilikii fungsi untuk mengembangkan kegiatan yang berkaitan dengan pendidikan dan pembelajaran masyarakat. Hal tersebut sangat penting sebagai sarana menanamkan nilainilai budaya bangsa, meningkatkan kebanggaan nasional, dan memperteguh jatidiri bangsa. Hasil-hasil penelitian yang dilakukan dan dipamerkan oleh museum situs arkeologi juga dapat dimanfaatkan untuk mendukung proses belajar mengajar khususnya di bidang sejarah dan kepurbakalaan. Melalui museum situs, siswa dapat melihat langsung potensi dan arti penting sumber daya budaya, serta upaya pelestariannya. Museum situs arkeologi dapat dimanfaatkan sebagai tempat belajar khususnya bagi siswa sekolah dari berbagai tingkatan. Melalui kegiatan permainan-permainan, kuis yang berkaitan dengan koleksi museum, penulisan hasil pengamatan, dan bimbingan edukasi, diharapkan dapat meningkatkan daya imajinatif dan kreatif siswa. Sebagai penunjang pembelajaran yang bersifat kreatif, museum situs dapat menyediakan ruang khusus untuk menggambar, membuat patung, melukis maupun berkaitan dengan situsnya.

Museum situs arkeologi harus dilengkapi sarana dan prasarana, sesuai dengan kaidah pariwisata Indonesia di antaranya harus bersih, indah, informatif, ramah, aman, serta didukung oleh pemadu yang harus 
menarik dan professional. Selain itu, museum situs purbakala juga dapat menyelenggarakan atraksi-atraksi khusus berupa simulasi kegiatan penelitian seperti ekskavasi. Dengan demikian pengunjung dapat merasakan dan mengetahui proses penelitian arkeologis di situs tersebut Untuk itu, diperlukan koordinasi yang harmonis antara berbagai pihak terkait dalam mengembangkan sarana dan prasarana museum situs.

Indonesia memiliki banyak situs purbakala yang sangat potensial untuk di kembangkan dan di manfaatkan sebagai pusat keunggulan (center of excellence) dalam rangka menanamkan nilai-nilai budaya bangsa, meningkatkan kebanggan nasional, dan memperteguh jatidiri bangsa. Selain itu, situs arkeologis juga dapat dikembangkan sebagai objek wisata budaya. Berkaitan dengan kenyataan di atas, maka di masa depan diharapkan akan semakin banyak lagi didirikan museum situs arkeologi.. Pendirian museum situs arkeologi hendaknya menyajikan informasi tentang potensi dan interpretasi yang telah di lakukan di situs tersebut, sehingga dapat mendukung pelestarian situsnya. Sebagaimana museum pada umumnya, selain memiliki fungsi rekreasi, museum situs arkeologis juga harus melaksanakan fungsi pembelajaran, khususnya dalam mendukung proses belajar mengajar di sekolah. Agar museum situs arkeologi dapat menjalankan tugas dan fungsinya dengan baik, perlu dilandasi dengan kebijakan secara nasional, didukung dengan kelembagaan, pendanaan, dan program-program yang tetap.

Beragam bentuk kegiatan dilaksanakan di Pusat Informasi Majapahit antara lain outbond yang mampu menampung sekitar 800 orang. Bertambahnya nilai penyajian dan bentuk aktivitas di PIM, mendongkrak nilai museum. Museum bukan lagi hanya sekedar tempat menyimpan benda-benda antik melainkan juga sebagai sarana hiburan keluarga dan kelompok masyarakat. Bahkan siswa-siswa di sekitar Mojokerto hampir setiap akhir pekan selalu mengadakan kegiatan kunjungan atau hanya sekedar melaksanakan kegiatan outbond di kompleks PIM tersebut. Koleksi di PIM (Museum Trowulan) adalah bendabenda cagar budaya yang ditemukan di sekitar Situs Trowulan atau peninggalan dari masa Majapahit. Melalui peninggalan tersebut kita dapat mengetahui aspek budaya yang pernah terjadi pada zaman Majapahit seperti bidang pertanian, irigasi, arsitektur, perdagangan, perindustrian, agama dan kesenian.

Dengan justifikasi bahwa budaya etnik tertentu lebih tinggi atau lebih 'beradab' daripada yang lain. Bahwa pada akhirnya hubungan lintas budaya itu menghasilkan proses asimilasi, akulturasi, adopsi, dan sebagainya adalah suatu proses yang alamiah yang merupakan bagian dari 'process to be Indonesia'.

\section{Historiografi Majapahit}

Taufik Abdullah mengatagorikan karya sastra sebagai sumber sejarah 
yang potensial. Terlepas dari masih adanya perdebatan tentang nilai faktual dari sumber lokal yang berupa karya sastra itu. Menurutnya apa yang tertulis dalam karya sastra dapat dikatagorikan sebagai fakta mental yang merupakan salah satu sumber penulisan sejarah. Lebih jauh Taufik Abdullah mengatakan bahwa karya sastra tersebut merupakan "pancaran dari kesadaran tentang segala hal yang wajar" di masa lalu. Serati babad, dan dokumen dinasti berbentuk karya sastra dapat pula dipakai sebagai alat untuk memahami berbagai pola perilaku kesejarahan dari masyarakat penganutnya. Dalam konteks ini, karya sastra telah menjadi bagian yang integral dengan sejarah sebagai sebuah tradisi. Karya sastra sebagai tradisi memiliki empat fungsi yakni: a) sebagai alat dokumentasi, b) sebagai media untuk mentransfer memori masa lalu antar generasi, c) sebagai alat membangun legitimasi, dan d) sebagai bentuk ekspresi intelektual. Nagarakretagama sebagai karya pujangga masa Majapahit, merupakan sumber sejarah yang penting. Historiografi Majapahit tentunya tidak bisa dilepaskan dengan sumber tertulis. Semua sumber baik lokal maupun asing harus diperlakukan sama, yang penting adalah perlu diterapkannya kritik sejarah yang normal dan kritis terhadap sumber-sumber itu.

Suatu peristiwa sejarah sering meninggalkan aspek sosial di dalamnya. Aspek sosial merupakan faktor yang penting bagi terciptanya kondisi yang mengantarkan suatu peristiwa sejarah. Agar pemahaman kesejarahan Majapahit lebih utuh, perlu mengenal konsep kosmogoni. Pandangan kosmogoni berasal dari doktrin Brahma (Hinduisme) dan doktrin Budhisme pada dasarnya memiliki kesamaan, bahwa Jagad Raya ini berbentuk lingkaran yang dikelilingi oleh beberapa wilayah, dan memiliki titik pusat yang disebut Gunung Meru (Robert Heine Geldern, 1930:28-78).

Pandangan kosmogoni ini berkembang, mempengaruhi pola berpikir manusia dan kemudian melahirkan konsep tentang hubungan manusia dengan jagad raya. Konsep hubungan manusia dengan jagad raya ini berpengaruh pula pada aktivitas kehidupan manusia, khususnya pada bidang politik dan kebudayaan. Hal ini dapat dibuktikan bahwa hampir semua kerajaan atau pola pemerintahan Asia Kuno terpengaruh oleh Kosmogoni itu. Gambaran kosmogoni dapat dilihat dengan nyata, bahwa raja dan kerajaannya adalah mikro kosmos (Jagad Raya), di samping itu raja dan kerajaannya menjadi titik pusatnya.

Konsep kepemimpinan dalam pemerintahan "Dewa Raja”, memandang Raja selain sebagai kepala negara juga dianggapnya sebagai keturunan wakil dewa, telah membudaya pada masyarakat Jawa sejak masa lampau. Lebih lanjut dapat dikatakan bahwa kekuasaan raja didukung oleh suatu predikat religius magis, yang kemudian masyarakat memiliki anggapan magis terhadap kekuasaan raja. Anggapan magis ini memunculkan penghormatan luar biasa pada raja dan masyarakat menyakralkan rajanya. Di samping 
itu keturunan raja beserta lingkaran keluarga raja, ikut mendapat penghormatan yang sakral dan menjunjung martabatnya, sehingga terciptalah sebuah lapisan masyarakat elite yang disebut dengan bangsawan. Raja dan keluarga raja sebagai micro cosmos, menjadi titik pusat yang dianggap sakral dalam pandangan masyarakatnya. Para bangsawan ini menempati posisi di pemerintahan, serta menjadi rajaraja kecil di daerah. Mereka masuk dalam lapisan sosiial mapan, terpandang dan sangat dihormati oleh masyarakat. Pandangan, penghormatan dan penghargaan itu menyebabkan lapisan bangsawan itu semakin kokoh. Dalam suatu kerajaan terdapat dua lapisan masyarakat, yaitu pertama lapisan atas (bangsawan, priyayi, wong gede) yang biasanya sebagian menduduki jabatan sebagai pemerintah, kedua lapisan bawah, rakyat jelata, sering disebut dengan wong cilik atau kawulo alit.

Lapisan atas terdiri dari bangsawan keturunan raja secara langsung. Menurut derajat keturunannya mereka memiliki status dan prestise berbeda dalam masyarakat. Bangsawan jabatan merupakan pejabat pemerintahan yang diangkat oleh raja. Kelompok ini berasal dari lapisan bawah yang memiliki prestasi sehingga dapat mobilitas vertikal untuk menduduki jabatanjabatan tertentu. Kedudukan bangsawan jabatan ini biasanya mulai dari patih ke bawah yaitu aparat operasional, yang menjalankan perintah raja, baik itu yang berada di bidang sipil, militer maupun keagamaan. Lapisan bawah adalah masyarakat umum yang tidak menjabat dalam pemerintahan, dan yang melakukan profesi kehidupan seperti: pedagang; petani, tukang, buruh dan sebagainya.

Pada abad 14, kerajaan Majaphit terbesar di kawasan Nusantara, dan telah memiliki perangkat yang lengkap. Kerajaan Majapahit dalam pola pemerintahannya menganut konsep kosmogoni, hal ini dapat dimaklumi bahwa di dalamnya terdapat pengaruh dua kekuatan ajaran Hinduisme dan Budhisme. Dalam struktur pemerintahan Majapahit, raja memegang otoritas tertinggi dan dianggap sebagai penjelmaan Dewa di dunia. Raja sebagai titik pusat pemujaan dan penghambaan rakyat serta memiliki kharisma yang meluas di kalangan rakyatnya. Dalam rangka menegakkan kewibawaan politik dan stabilitas kekuasaan raja, maka raja mengangkat kerabatnya untuk menduduki jabatan yang penting di kerajaan Majapahit. Jabatan-jabatan yang diduduki oleh kerabat raja, antara lain: 1. Setelah kedudukan raja, terdapat jabatan Yuwaraja atau Kumaraja adalah jabatan yang diperuntukkan Putera atau Puteri Mahkota, yang kelak dipersiapkan calon raja atau ratu. Jabatan ini diperuntukkan anak raja yang tertua dari seorang permaisuri. 2. Jabatan Rakyan Mahamantri Katrini, jabatan ini semacam Dewan Menteri (koordinator), memiliki kedudukan penting setelah raja dalam hal pemerintahan. Mereka menerima perintah secara langsung dari raja. Namun Rakyan Mahamantri Katrini tidak secara langsung sebagai 
pelaksana perintah itu. Akan tetapi sebagai penerus perintah untuk bawahannya, yaitu pelaksana perintah yang memiliki jabatan Rakyan Mantri ri Pakirakiran. Jabatan Rakyan Mahamantri Katrini diduduki oleh saudara raja (adik-adik). 3. Jabatan Pahom Narendra atau disebut juga Bhattara Sapta Prabu, semacam lembaga pertimbangan (Dewan Pertimbangan Agung/DPA), dijabat oleh 7 orang keluarga raja, terdiri dar: a. raja; b. ayah sang raja, c. ibu sang raja, d. paman sang raja, e. bibi sang raja, f. adik sang raja, g. adik sepupu sang raja. ( N.J. Krom, tt.:195196).

Jabatan-jabatan di atas diduduki oleh keluarga dekat atau kerabat lingkaran darah terdekat dari raja yang memerintah. Pejabat-pejabat itu berkedudukan di pusat kerajaan, dan merupakan pemerintahan teras, yang pelaksanaan kerjanya seharihari dibantu oleh pejabat-pejabat yang diangkat bukan dari kerabat raja. Di samping pemerintahan pusat, penguasa-penguasa daerah atau pemerintah Negara bagian, dipegang oleh raja-raja kecil (kepala daerah), dengan gelar paduka bhattara I atau sering diucapkan Bhra I (bhre), yang terdiri atas para keluarga raja juga. Jadi raja kecil atau kepala daerah dipegang oleh keluarga raja, sehingga hubungan raja dengan para raja kecil di daerah terjalin dalam bentuk clientship, yaitu adanya hubungan ikatan kekeluargaan antara seseorang penguasa politik tertinggi dengan orang yang diberi kuasa untuk menjalankan sebagian dari kekuasaan penguasa tersebut (Sartono Kartodirjo, 1969:17). Pola kekuasaan raja-raja kecil merupakan miniatur dari pola pusatnya, termasuk didalamnya memiliki struktur birokrasi yang sama dan pola serta setting kraton yang sama, namun bentuknya lebih kecil. Di samping itu sistem kerabat jabatan penting juga dilakukan pada penguasa Daerah, dan statusnya sebagai wakil raja Majapahit di daerah yang dikuasai. Sebagai kontrol kesetiaan diwajibkan memberikan upeti.

Bila di atas diterangkan tentang bangsawan kerabat raja yang merangkap sebagai pejabat kerajaan Majapahit, maka ada pula pejabat kerajaan Majapahit yang berasal di luar lingkup kerabat raja, misalnya: 1. Rakyan mantra ri Pakirakiran, terdiri dari sekelompok pejabat tinggi seperti Dewan Menteri (kabinet), yang berfungsi sebagai badan pelaksana pemerintahan hari-an, dipimpin oleh rakyan mapatih atau patih hamengkubhumi (Hassan Djafar, 1978:41). Anggotanya terdiri rakyan kanuruhan sebagai contoh Gajah Mada termasuk di dalam badan rakyan mantra ri pakirakiran, ia mendapat gelar sang mahamantri mukya rakyan mapatih. Di samping itu ada pemerintah harian yang khusus menangani bidang militer, yaitu yang disebut juru pangalasan. 2. Dharmadyaksa, merupakan pejabat tinggi di Majapahit yang bertugas dalam bidang keagamaan dan hukum. Di kerajaan Majapahit terdapat dua buah Dharmadyaksa, yaitu pertama Dharmmadyaksa ring kasaiwan bertugas membina kehidupan dan hukum-hukum agama Hindu Syiwa, sedangkan Dharmadyaksa ring kasogatan bertugas 
membina dan menangani bidang hukum serta agama Budha. Dua pejabat keagamaan ini dibantu oleh banyak Dharma Upapatti. 1. Mantri Bhujangga, merupakan jabatan untuk kelompok cendekiawan seperti para ahli hukum, para penyair dan para ilmuwan yang berada di lingkungan istana Majapahit. Mereka berfungsi sebagai penasehat masalah keilmuan keduniawian dan memberikan tuntunan rohaniyah. 2. Pejabat lain yang ada di Majapahit ialah a. Mantri atau Mandarin; para tanda (kepala jawatan), b. para gusti dan c. wadyahaji, serta d. bhayangkari. Untuk jabatan para gusti dan para wadyahaji memiliki ciri khusus. Kedua jabatan itu merupakan jabatan rendahan yang diduduki oleh kerabat raja.

Struktur birokrasi Kerajaan Majapahit menempatkan jabatan Rakryan Mapati, Patih Hamangkhubumi, atau disebut juga Apatih Ring Tiktawibwadhika seperti yang pernah dijabat oleh Gadjah Mada, sebagai pemimpin politik dan sekaligus sebagai panglima perang pada struktur birokrasi kerajaan di tingkat pusat. Berkesan kuat bahwa seorang Perdana Menteri, selain menjabat di sektor pemerintahan, dia menjadi komandan pertahanan keamanan serta menjadi pemimpin perang. Di tingkat daerah, para patih yang disebut Sang Mapatih atau Rakryan Mapatih juga memiliki fungsi yang sama dengan patih yang berada di pusat. Tidak hanya pemisahan yang tegas antara fungsi sipil atau administratif dengan fungsi militer dalam tradisi politik di
Indonesia. Diperkuat lagi oleh pengidentifikasian konsep ksatria yang mewakili kelompok sosial yang memiliki kekuasaan atas poitik serta militer. Para raja serta kerabatnya selalu dikaitkan dengan kasta ksatria, sementara itu ksatria juga melekat sebagai salah satu simbol dan jiwanya tentara. Pengidentifikasian itu tidak hanya berhenti pada masa kerajaan-kerajaan yang dipengaruhi Hindhu-Budha, melainkan juga ketika Islam telah berkembang menjadi dasar ideologis dari kerajaankerajaan seperti Demak dan Mataram baru.

\section{Penguat Identitas Bangsa}

Menurunnya kecintaan bangsa ini pada tanah air bermula dari hilangnya kesadaran sejarah, geografis, dan budaya kita. Kecintaan bukan sekedar kondisi emosi yang irasional, melainkan suatu perkembangan pengetahuan yang melibatkan kepribadian seseorang atau kelompok dalam masyarakat. Mencintai meliputi proses learning yang melibatkan sikap aktif mengetahui dan menghendaki. Berbeda dengan pemikiran Jerman yang membedakan ungkapan mengetahui (vernunf), memahami (verstand), dan mencintai (verlieben). Masyarakat Jawa mengaitkan kecintaan dengan pembiasaan dalam perjumpaan dan hidup keseharian (liteng tresno jalaran soko kulino).

Para pendiri bangsa menyadari realitas sejarah, geografis, dan budaya sebagai modal perjuangannya guna kemerdekaan bangsanya. 
Berbeda dengan para politisi saat ini yang berjuang untuk kekuasaan bukan mensejahterakan masyarakat. Dalam perjuangannya, mereka menanggalkan landasan itu, sebaliknya telah mengutamakan kepentingan pribadi dengan bergaya hidup serta berpola pikir kebarat-baratan. Kesadaran identitas terhadap keatuan geografis, sejarah hidup bersama, dan tradisi budaya lokal, serta koeksistensi kemajemukan yang berlangsung ribuan tahun terabaikan. Para generasi bangsa secara perlahan tercerabut dari akar kecintaannya pada Tanah Air. Orang tak lagi mengerti identitas dan Jati diri kebangsaan dan keindonesiaannya.

Dalam konsep kearifan lokal, tanah sering dimengerti sebagai asal, tempat hidup dan kembalinya manusia ketika mati. Manusia berasal dari tanah yang hidupnya tidak bisa dilepaskan dengan air, bahkan tubuh manusia sebagian besar terdiri dari air. Maka, tanah dan air menjadi simbol tempat hidup dan proses kehidupan. Itulah ibu pertiwi tempat laki dan perempuan penduduk negeri menjaga mata rantai kehidupan tanpa henti. Cinta kepada Tanah Air menuntut kemauan untuk meninjau kembali wawasan keindonesiaan yang kini tengah berkembang. Cara pandang paradoksal yang melampaui batas etnik, kelompok, dan kepentingan golongan perlu ditumbuhkan terusmenerus. Dengan demikian, identitas keindonesiaan dan identitas lokal atau kelompok tidak saling mengekslusifkan. Akan tetapi dipenuhi sikap penerimaan realitas konkret yang makin menegaskan identitas, kerukunan atau kebersamaan, serta memperkaya kehidupan.

Untuk menunjukkan kesadaran tersebut, Bertens (1993:52-53) membedakan antara pengenalan dan kesadaran. Mengenal adalah bila kita melihat, mendengar atau merasakan sesuatu, sedangkan kesadaran merupakan kesanggupan manusia untuk mengenal dirinya sendiri dan berefleksi tentang dirinya. Beda dengan binatang yang tak bisa mengenali tentang dirinya sendiri. Hanya manusia yang memiliki kesadaran tersebut. Dalam proses pengenalan, manusia bukan saja berperan sebagai subjek, namun ia juga sebagai objek. Umumnya orang tak menyadari kalau dalam dirinya ada mata hati yang menilai tindakannya. Agar mata hati senakin tajam tentunya diperlukan pengetahuan sehingga perlu proses pembelajaran dalam kehidupan. Bertens (1993: 64) mengungkapkan bahwa mata hati yang dilatih dan dibentuk dengan baik, dapat mengarahkan secara tepat dalam hidup ini. Dengan demikian, dalam pembentukan jati diri pribadi, masing-masing individu perlu mengenali, memahami, menghayati dirinya sendiri dengan kesadaran penuh sebagai tindakan untuk turut membangun identitas bangsa.

Penguatan identitas bangsa akan lebih efektif jika semua lapisan masyarakat terlibat didalamnya. Diantaranya bisa dilakukan melalui pendidikan, baik formal maupun informal. Dunia pendidikan hendaknya dibenahi sebelum nanti mampu menguatkan identitas bangsa. Oleh 
karena sering kali dalam proses pembelajarannya tak humanis: tak menyentuh kepada manusianya, tak menyentuh kepada siswa, guru, dan tenaga kependidikan lainnya. Terlalu jauh kebijakan konsep pendidikan dengan pelaku peserta pendidikan. Akibatnya, setiap pihak berjalan sendiri sesuai dengan keyakinan masing-masing yang ternyata menyimpang dari makna dan hakikat pendidikan.

Dengan pendidikan yang humanis, penguatan identitas bangsa dapat dilakukan secara berkelanjutan. Mengembangkan kreatifitas dalam rangka memahami identitas bangsa hendaknya diarahkan pada proses pembelajaran para peserta didik. Berkaitan dengan itu desain kurikulum saat ini perlu ditinjau. Oleh karena dengan beban seberat saat ini, baik peserta didik maupun guru/dosen hanya tertarik dengan aspek-aspek kognitif. Terbatasnya akses internet serta koleksi perpustakaan yang dimiliki tidak mendorong mereka menerapkan proses pembelajaran inquiry. Proses individualisasi pengetahuan tidak terjadi, sehingga peserta didik akan segera "melupakan" materi begitu semester berganti. Kemampuan sintetik dan lintas-disiplin tidak dikembangkan karena "mempersulit" peserta didik dan guru sendiri. Guru maupun dosen tidak terbiasa memberikan tantangan intelektual yang cukup. Materi kuliah dan ujian yang tidak banyak perubahan dan pemutakhiran, sehingga berkembang budaya "baceman" di kalangan mahasiswa.
Kearifan ungkapan kesatuan paradoksal seperti tanah air, merah putih, jiwa raga, siang-malam, interrelasi pria-wanita sebagai sumber mata rantai kehidupan, ngalah luhur wekasane (mengalah tetapi mulia di akhir) perlu dibiasakan di tengah masyarakat. Dengan demikian, cara berfikir dan kondisi batin tiap warga masyarakat tidak terkungkung dalam satu dimensi pandangan dan ideologi. Kecuali itu, pembiasaan kearifan kesatuan paradoksal juga akan menumbuhkan sikap hormat dan penghargaan terhadap perbedaan. Kearifan kesatuan paradoksal, tradisi sehari-hari seperti makna nama pasaran dan sebutan hari, bulan, legenda, cerita maupun tinggalan budaya di museum dapat dimanfaatkan sebagai sarana pembiasaan dan penyadaran akan kecintaan terhadap Tanah Air. Melalui pemeliharaan kearifan lokal dan tradisi budaya diharapkan para pemimpin negeri ini lebih memperhatikan kesejahteraan bersama, dan masa depan Tanah Air.

Berkenaan dengan pemahaman tersebut, ketika seseorang telah mengenal, memahami, dan menghayati secara utuh tentang dirinya, maka ketika itu ia telah menemukan jati dirinya (Pradipta 2004: 41-43). Seseorang yang telah mencapai kondisi ini akan selalu berbuat baik. Tindakan tersebut dalam budaya Jawa dikenal dengan lelaku Memayu Hayuning Bawono. Dalam arti seseorang telah memiliki kesanggupan dan kemampuan menyempurnakan hidup manusia lahir-batin, jasmanirohani, jiwa-raga, materiil-spiritual, individual-sosial, nasional-internasi- 
onal, dan dunia-akhirat. Berkenaan dengan meneguhkan jati diri adalah suatu proses penumbuhan dan pengembangan nilai-nlai luhur yang terpancar dari hati nurani melalui mata hati kita, dan direfleksikan dalam pemikiran, sikap dan perilaku. Sejarah telah menyediakan banyak materi. Dalam butir Peraturan Menteri Pendidikan Nasional Nomor 22 Tahun 2006 tentang standar Isi, tujuan pembelajaran sejarah adalah menumbuhkan pemahaman peserta didik terhadap proses terbentuknya bangsa Indonesia melalui sejarah yang panjang dan masih berproses hingga kini dan masa yang akan datang. Tujuan ini mengharapkan siswa memahami identitas dirinya sebagai bangsa Indonesia. Jika mengacu pada tujuan itu, peran pemerintah yang semestinya paling awal mengubah pola pengajaran sejarah menjadi lebih menarik, netral sebagai fakta, dan pada akhirnya membebaskan anak bangsa ini dari belenggu sejarah negeri sendiri.

\section{Penutup}

Untuk penguatan identitas bangsa diperlukan kemauan politik oleh pengambil kebijakan. Tinggalan budaya di museum bisa dijadikan sumber inspirasi. Realitas historis menunjukkan bahwa Indonesia merupakan bangsa besar perlu dipahami oleh masyarakat. Untuk itu diperlukan strategi dan komunikasi tertentu secara berkelanjutan. Pembelajaran dengan model lawatan ke museum dan situs sejarah secara langsung menjadi alat penting dalam proses sosialisasi nila-nilai nasionalisme pada masyarakat khususnya generasi muda. Dalam proses sosialisasi ini, bahan ajar sejarah merupakan salah satu media penting untuk penguatan identitas bangsa. Melalui bahan ajar dapat dihasilkan definisi fungsional mengenai identitas bangsa, yang kemudian ditransformasikan menjadi sebuah ideologi dan budaya.

Mengenal sejarah sangat penting, bukan saja karena dari sana orang belajar tak mengulangi kesalahan yang sama, sekaligus menegaskan pijakan melangkah ke masa depan. Ungkapan tersebut menyiratkan pengenalan dan pemahaman sejarah yang benar berperan penting dalam pembentukan karakter suatu bangsa. Oleh karena itu, penanaman ingatan sejarah bangsa penting menjadi bagian dari sistem pendidikan. Sayangnya, pembelajaran sejarah di sekolah kerap kali terkendala stigma membosankan. Cap itu muncul setelah sekian lama ada anggapan bahwa sejarah adalah pembelajaran yang "kering', tidak menarik, baik dari segi materi maupun metode belajar, dan tidak penting" di tengah berbagai perkembangan keilmuan teknologi serta tuntutan kepraktisan hidup saat ini. Dalam pembelajaran sejarah, penggunaan metode menghafal masih diperlukan. Akan model pembelajaran yang lebih integratif, mengenalkan anak dengan obyek sejarah secara langsung, serta melibatkan sarana audio visual, sudah tak terelakkan kebutuhannya. Belajar sembari ke museum ataupun tempat bersejarah lainnya lebih merefleksi- 
kan peristiwa sejarah dan membangun imajinasi siswa.

Upaya menanamkan identitas bangsa seharusnya sudah dimulai sejak pendidikan dasar. Pendidikan sebagai pengantar anak didik ke masa depan perlu didorong agar menjadi gerakan budaya yang memunculkan tokoh lokal yang sanggup menghadapi ketidakpastian dan ketidakjelasan secara kreatif. Sebagai penerus bangsa, peserta didik diharapkan mampu tampil sebagai pemimpin baru di berbagai bidang, ekonomi, sosial, budaya dan politik. Sekolah dan kampus perlu mendisain ulang kurikulumnya menjadi tidak "padat akademik" sehingga pendalaman materi dan pengembangan kepribadian peserta didik lebih diperhatikan dengan alokasi waktu lebih memadai. 


\section{Daftar Pustaka}

Abraham Nurcahyo. 1990. Celengan Koleksi Museum Trowulan: Studi Teknik dan Fungsi. Skripsi. Yogyakarta: Fakultas Sastra UGM.

Bambang Purwanto. 2006. Gagalnya Historiografi Indonesiasentris. Yogyakarta: Ombak.

Bertens, K. 1993. Etika. Jakarta: Gramedia Pustaka Utama.

Budya Pradipta. 2004. Memayu Hayuning Bawono: Tanda Awal Indonesia Menjadi Pusat, Obor, dan Pemimpin Dunia. Jakarta: Kencana.

Crowther, D. 1991. "Archaeology, Material Culture and Museums". Dalam Susan M.

Edi Sedyawati. 1996. Kumpulan Makalah. Jakarta: Direktorat Jendral Kebudayaan Depdikbud.

Hassan Djafar. 1978. Girindrawarddhana Beberapa Masalah Majapahit Akhir. Jakarta: Direktorat Pembinaan Penelitian dan Pengabdian Masyarakat Dirjen. Pendidikan Tinggi Dep. P \& K, hlm. 41.

Iseminger, W.R. 1997. "Public Archaeology at Caholia". Dalam John H. Jameson, Jr. (ed.) Presenting Archaeology to the Public. London: Altamira Press.

N.J. Krom. TT. "Sapta Prabhu”. Dalam T.B.G., LVI. Jakarta: Direktorat Pembinaan Penelitian dan Pengabdian Masyarakat Dirjen. Pendidikan Tinggi Dep. P \& K.

Pearce (ed.). 1991. Museum Studies in Material Culture. Washington: Smithsonian Institution Press.
Robert Heine Geldern. 1930. Wet bild und Bauform in sudostasien," weiner Beitrage Zur Kunst un Kullurgeschichte Asians.

Sartono Kartodirjo. 1969. "Struktur Sosial dari Masyarakat Tradisional dan Kolonial" dalam Lembaran Sejarah.

Slamet Mulyana. 1979. Nagarakretagama dan Tafsir Sejarahnya. Jakarta: Bhratara.

Soebijantoro dan Abraham Nurcahyo. 2007. Museum, Kesadaran sejarah dan Pariwisata serta Pemberdayaannya. Jurnal Pendidikan. Madiun: IKIP PGRI Madiun.

Taufik Abdullah, (ed). 1986. Literature and History. Yogyakarta: Gadjah Mada University Press.

Taufik Abdullah dan Abdurrachman Surjomihardjo. 1992. "Pengantar: Sejarah dan Historiografi" (ed.). Ilmu sejarah dan Historiografi, arah dan Perspektif. Jakarta: Gramedia.

Theodore Gauthier Pigeaud. 1962. Java in the 14th Century, A Study in Cultural History: The NegaraKertagama by Pakawi Parakanca of Majapahit, 1365 AD The Hague, Martinus Nijhoff. 